\title{
Efforts to improve activities and learning outcomes IPS through Cooperative Learning Models Numbered Heads Together
}

\section{Upaya untuk meningkatkan kegiatan dan hasil pembelajaran IPS melalui model pembelajaran Kooperatif Learning tipe Numbered Heads Together}

\author{
Nuriyasmiati $^{1}$, Khairani ${ }^{2}$ \\ ${ }^{1}$ Social Education Program, Postgraduate Faculty, Universitas Negeri Padang \\ ${ }^{2}$ Universitas Negeri Padang
}

\begin{abstract}
This research was based on the fact that the activity and learning results of students of grade IX.5 at SMPN 5 Bukittinggi were low. The purpose of this research was to gain information and discuss the improvement of activity and learning results of Social Study by using cooperative model type Numbered Heads Together. This research was a Classroom Action Research (CAR) with qualitative approach. There were 2 cycles in this research, each of which consisted of 4 meetings namely planning, application, observing, and reflecting procedures. The subject of this research was the students of grade IX.5 of SMPN 5 Bukittinggi which consisted of 34 students; 15 females and 19 males. The instruments used in this research were test, students' activity observation sheet, questionnaire, interview, documentations, and field notes. The data was analyzed by using percentage technique. The result of this research showed that the application of Numbered Heads Together could improve the activity and learning result of Social Study of grade IX.5 students of SMPN 5 Bukittinggi.
\end{abstract}

Keywords: Social study learning activity, learning result, cooperative model, type numbered heads together. distribution, and reproduction in any medium, provided the original work is properly cited. (C2018 by author

\section{PENDAHULUAN}

Ilmu Pengetahuan Sosial adalah kajian yang memusatkan perhatiannya pada aktivitas kehidupan manusia. Yang menjadi fokus IPS adalah berbagai aktivitas manusia dalam berbagai dimensi kehidupan sosial sesuai dengan karakteristik manusia sebagai makhluk sosial. Pendidikan IPS lebih ditekankan pada bagaimana cara menerapkan ilmu-ilmu sosial dalam proses pendidikan atau lebih kepada penerapannya. Pembelajaran IPS harus dirancang sedemikian rupa dengan menggunakan berbagai macam model pembelajaran kooperatif (Siti Fatimah, 2015: 4)

Pelajaran IPS merupakan salah satu mata pelajaran wajib di SMP/MTs dengan ruang lingkup materi geografi, sejarah, sosiologi, antropologi, serta ekonomi, yang disebut dengan IPS terpadu yang diajarkan oleh satu orang guru dan geografi dijadikan sebagai platform (titik tolak) dengan pertimbangan semua kejadian terkait dengan lokasi. Sesuai dengan tuntutan kurikulum sekarang yaitu kurikulum 2013, bahwa dalam proses pembelajaran sangat dituntut keaktifan peserta didik baik secara fisik maupun phsikis, peserta didik harus mampu menemukan sendiri konsep yang sedang dipelajarinya melalui kegiatan mengamati, menanya, mengumpulkan data,mengasosiasi dan menyimpulkan, sedangkan guru hanya bertindak sebagai fasilitator, 
inspirator, motivator dan mediator.Untuk itu seorang guru harus bisa mendesain berbagia macam model pembelajaran kooperatif yang menantang bagi peserta didik yang bisa membuat mereka aktif dalam belajar sehingga nanti berdampak terhadap hasil belajar mereka.(Nurman Sumantri, 2001).

Sementara itu kenyataan yang ditemui ketika berlangsungnya pembelajaran IPS di SMPN 5 Bukittinggi di kelas IX.5, berdasarkan catatan lapangan, pengamatan , observasi awal dan berdasarkan pengalaman penulis serta hasil wawancara dengan guru yang masuk ke kelas IX.5 ternyata sebagian besar peserta didik belum belajar secara aktif dan efektif sehingga peran guru yang seharusnya sebagai fasilitator, mediator,inspirator dan motivator belum tercapai sepenuhnya, suasana dan proses pembelajaran masih memiliki banyak kekurangan,yaitu rendahnya aktivitas peserta didik selamaprosespembelajaranberlangsung, peserta didik sering merasa jenuh dalam belajar, malas bertanya, malas menanggapi,malas memberi penguatan terhadap pendapat teman, malas memberi saran, tidak mengumpulkan tugas tepat waktu, tidak aktif dalam kelompok, sedikit sekali yang mau presentase ke depan kelas, dan masih banyak peserta didik yang tidak berani menyimpulkan pelajaran, serta tidak bersemangat dalam belajar, selain itu kebiasaan dalam proses belajar mengajar methode pembelajaran yang diterapkan guru belum bervariasi, sehingga belum menarik bagi peserta didik, guru masih memiliki paradigma mengajar belum membelajarkan, guru masih sering menjadi pusat pembelajaran dengan menggunakan metode konvensional, guru belum lagi memberdayakan potensi dirinya untuk mendesaian suatu pembelajaran yang inovatif dengan berbagai macam model pembelajaran yang dapat meningkatkan keaktifan peserta didik dalam belajar, kondisi belajar yang seperti ini berdampak terhadap hasil belajar IPS peserta didik, dimana hasil belajar IPS peserta didikpun rendah, banyak peserta didik yang tidak tuntas dalam Penilaian Harian (PH) sesuai dengan Kriteria Ketuntasan yang ditetapkan yaitu 75.

Dengan terdapatnya kesenjangan antara yang diharapkan dengan kenyataan yang ada dan agar permasalahan ini tidak semakin berlanjut terus yang dapat menurunkan kualitas pembelajaran maka perlu dilakukan sesuatu pembaharuan dalam proses pembelajaran melalui penerapan model-model pembelajaran, dengan harapan dapat meningkatkan aktivitas dan hasil belajar IPS peserta didik. Oleh karena itu, peneliti mencari solusi dari permasalahan ini, yaitu melakukan suatu pembaharuan dalam proses pembelajaran dengan menggunakan model pembelajaran Kooperatif TipeNumbered Heads Togethermelalui Penelitian Tindakan Kelas yang berjudul "Upaya Meningkatkan Aktivitas dan Hasil Belajar IPS Melalui Model Pembelajaran Kooperatif Tipe Numbered Heads Together di kelas IX.5 SMP Negeri 5 Bukittinggi “. Penelitian ini bertujuan untuk mendapatkan informasi dan membahas tentang peningkatan aktivitas dan hasil belajar IPS peserta didik kelas IX.5 dengan penerapan model pembelajaran NHT. Hasil penelitian ini diharapkan dapat bermanfaat bagi peneliti atau guru sendiri untuk meningkatkan dan pengembangan profesionalisme sebagai seorang guru mata pelajaran IPS kelas IX.5 SMP Negeri 5 Bukititnggi. Dan untuk bahan diskusi dengan teman sejawat, dalam rangka perbaikan pembelajaran. Sedangkan untuk peserta didik diharapkan peserta didik menjadi aktif dalam proses pembelajaran karena mendapatkan pengalaman baru dalam model pembelajaran

Aktivitas merupakan hal penting dalam pembelajaran sebab, belajar pada prinsipnya merupakan perubahan tingkah laku. Menurut Sadirman, A. M (2006: 194) “Tidak ada belajar kalau tidak ada aktivitas".Aktivitas sangat diperlukan dalam belajar karena pada prinsipnya belajar adalah berbuat, menentukan arah perbuatan untuk mencapai tujuan, dan menyeleksi perbuatan yakni perbuatan mana yang akan dikerjakan. Dalam dinamika kehidupan manusia, berpikir dan berbuat sebagai suatu rangkaian yang tidak dapatdipisahkan. begitu juga dalam belajar sudah barang tentu tidak mungkin meninggalkan dua kegiatan itu, yaitu berpikir dan berbuat. Aktivitas berdampak terhadap hasil belajar

Hasil belajar dapat diartikan sebagai suatu proses perubahan tingkah laku akibat adanya interaksi individu dengan lingkungannya. Rocklin (dalam Slavin, 1994) mengatakan: bahwa belajar adalah perubahan pada seseorang yang disebabkan karena adanya pengalaman.Hasil belajar merefleksikan seberapa jauh tujuan pembelajaran telah tercapai maka penggolongan hasil belajar dapat pula didasarkan pada penggolongantujuan belajar. Berdasarkan teori taksonomi bloom, hasil belajar dalam rangka studi dicapai melalui tiga ranah, yaitu ranah kognitif, ranah afektif dan ranah psikomotor, maka hasil belajar dapat digolongkan atas tiga ranah tersebut.

Pembelajaran Numbered Heads Together merupakan salah satu tipe pembelajaran kooperatif yang menekankan pada struktur khusus yang dirancang untuk mempengaruhi pola interaksi peserta didik dan memiliki tujuan untuk meningkatkan penguasaan akademik. Dengan melibatkan para peserta didik dalam menelaah bahan yang tercakup dalam suatu pelajaran dan mengecek pemahaman mereka terhadap isi pelajaran tersebut, serta mengembangkan keterampilan. Keterampilan yang dimaksud antara lain berbagi tugas, aktif bertanya, menghargai pendapat orang lain, mau menjelaskan ide atau pendapat, bekerja dalam kelompok (Herdian, 2011).

Menurut Anita Lie (2002:58) Numbered Heads Together (NHT) dikembangkan oleh Spencer Kagan ( 1992) atau kepala bernomor adalah suatu tipe dari pengajaran kooperatif yang memberikan kesempatan kepada 
peserta didik untuk saling membagikan ide -ide dan mempertimbangkan jawaban yang paling tepat. Selain itu Numbered Heads Together juga mendorong peserta didik untuk meningkatkan semangat kerjasama mereka. Melalui teknik ini, peserta didik belajar melaksanakan tanggung jawab pribadinya yang saling berkaitan dengan rekan-rekan kelompok. Teknik ini bisa juga digunakan dalam semua mata pelajaran dan semua tingkat usia anak didik.

\section{METODE}

Jenis penelitian yang dilakukan adalah penelitian tindakan kelas (classroom action recearch) dengan pendekatan kualitatif. PTK adalah penelitian tindakan (action research) yang dilakukan oleh guru yang sekaligus sebagai peneliti di kelasnya atau bersama-sama dengan orang lain (kolaborasi) dengan jalan merancang, melaksanakan dan merefleksikan tindakan secara kolaboratif dan partisivatif yang bertujuan untuk memperbaiki atau meningkatkan mutu (kualitas) proses pembelajaran di kelasnya melalui suatu tindakan (treatment) tertentu dalam suatu siklus.(Kunandar 2008: 44-45).

\section{HASIL DAN PEMBAHASAN}

Pelaksanaan penelitian sudah dilakukan sesuai dengan rancangan penelitian tindakan yang telah dibuat sebelumnya yakni terdiri dari 2 siklus, siklus I terdiri dari 4 kali pertemuan, siklus II terdiri dari 4 kali pertemuan. Setiap siklus terdiri dari empat tahapan yaitu perencanaan, pelaksanaan, observasi dan refleksi. Dan sebelum melakukan penelitian tindakan penulis melakukan pengambilan data pra siklus untuk melihat kondisi awal peserta didik dalam aktivitas dan hasil belajar. Data hasil penelitian peningkatan aktivitas dan hasil belajar peserta didik melalui model pembelajaran kooperatif tipe Numbered Heads Together ini diperoleh langsung dari catatan observer selama proses pembelajaran berlangsung. Dalam penelitian ini peneliti dibantu oleh 2 orang observer yaitu.ibuk Yendri Netti dan ibuk Sukmawati. Hasil pengolahan Data observasi dapat dilihat dari tabel dan grafik rekapitulasi dibawah ini.

Tabel 1 Rata-rata persentase aktivitas peserta didik Pra siklus, Siklus I dan siklus 2

\begin{tabular}{|c|c|c|c|c|}
\hline \multirow[b]{2}{*}{ No } & \multirow[b]{2}{*}{$\begin{array}{c}\text { Jenis Aktivitas Peserta didik } \\
\text { ( indikator) }\end{array}$} & \multirow[b]{2}{*}{$\begin{array}{c}\text { Pra siklus } \\
\%\end{array}$} & \multicolumn{2}{|c|}{ Rata-rata } \\
\hline & & & $\begin{array}{c}\text { Siklus } 1 \\
\%\end{array}$ & $\underset{\%}{\operatorname{Siklus}} \mathbf{1 1}$ \\
\hline 1 & Bertanya & 17,65 & 56,62 & 80,15 \\
\hline 2 & Menjawab pertanyaan & 23,53 & 62,5 & 85,30 \\
\hline 3 & Kerja sama dalam kelompok & 35,29 & 67,65 & 90,44 \\
\hline 4 & Menyelesaikan tugas tepat waktu & 32,35 & 73,53 & 87,52 \\
\hline 5 & Presentase kedepan kelas & 29,41 & 58,82 & 90,46 \\
\hline 6 & Keaktifan dalam kelompok diskusi & 26,47 & 73,53 & 91,19 \\
\hline 7 & Semangat dalam belajar & 58,82 & 72,06 & 87,52 \\
\hline
\end{tabular}

Sumber: Diolah dari data primer, 2018. 


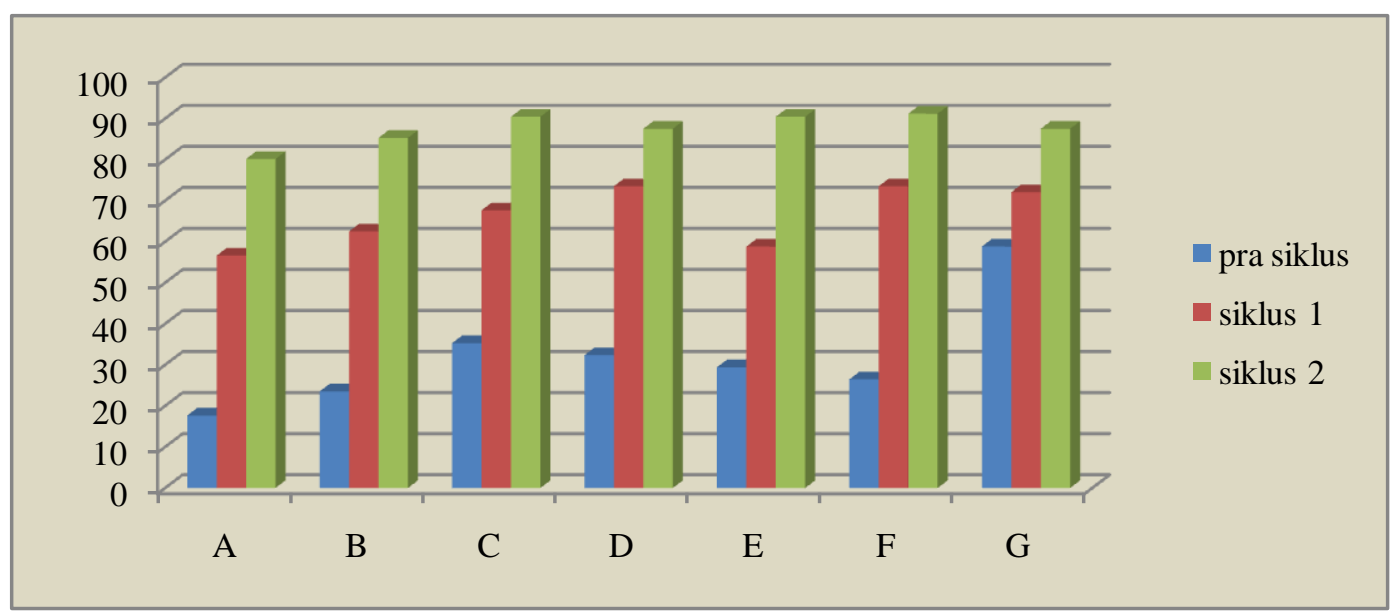

Grafik I: Diagram Batang rata-rata persentase aktivitas peserta didik Pra siklus, siklus I dan Siklus II

Keterangan :

A = Bertanya

$\mathrm{B}=$ Menjawab pertanyaan

$\mathrm{C}=$ Kerja sama dalam kelompok diskusi

$\mathrm{D}=$ Menyelesaikan tugas tepat waktu

$\mathrm{E}=$ Presentase kedepan kelas

$\mathrm{F}=$ Keaktifan dalam kelompok

$\mathrm{G}=$ Semangat dan belajar

Dari tabel dan grafik diatas dapat disimpulkan, Aktivitas bertanya pada pra siklus $17,65 \%$ siklus I meningkat menjadi 56,62 \% dan siklus II 80,15\%. Aktivitas Menjawab pertanyaan pra siklus 23,53\%, siklus I meningkat $62,5 \%$ dan siklus II meningkat menjadi $85,30 \%$. Kerja sama dalam kelompok pra siklus 35,29\%, meningkat pada siklus I 67,65\% dan pada siklus II menjadi 90,44\%.Menyelesaikan tugas tepat waktu pada pra siklus 32,35\%, meningkat pada siklus I 73,53\% dan siklus IImenjadi 87,52\%. Presentase kedepan kelas pra siklus $29,41 \%$ siklus I meningkat $58,82 \%$ dan siklus II meningkat menjadi 90,46\%. Keaktifan dalam kelompok diskusi pra siklus $26,47 \%$, siklus I meningkat $73,53 \%$ dan siklus II menjadi $91,19 \%$. Semangat dalam belajar pra siklus 58,82\% meningkat pada siklus I 72,06\% dan pada siklus II meningkat menjadi 87,52\%.

Setelah selesai siklus I dan II kemudian diberikan tes. Dari analisis hasil belajar diperoleh data hasil tes seperti pada tabel dibawah ini:

Tabel 2 Rata-rata Pencapaian KKM Hasil Belajar peserta didik pra siklus, siklus I dan siklus II

\begin{tabular}{ccccc}
\hline Siklus & \multicolumn{2}{c}{ Siswa yang telah tuntas $(\mathbf{k k m 7 5})$} & \multicolumn{2}{c}{ Siswa yang belum tuntas (kkm 75) } \\
\cline { 2 - 5 } Pra siklus & Orang & Persentase & Orang & Persentase \\
I & 15 & 44,12 & 19 & 55,88 \\
II & 25 & 73,53 & 9 & 26,47 \\
& 32 & 94,12 & 2 & 5,88 \\
\hline
\end{tabular}


Untuk lebih jelasnya Rata-rata ketuntasan peserta didik dapat dilihat dari grafik 2:

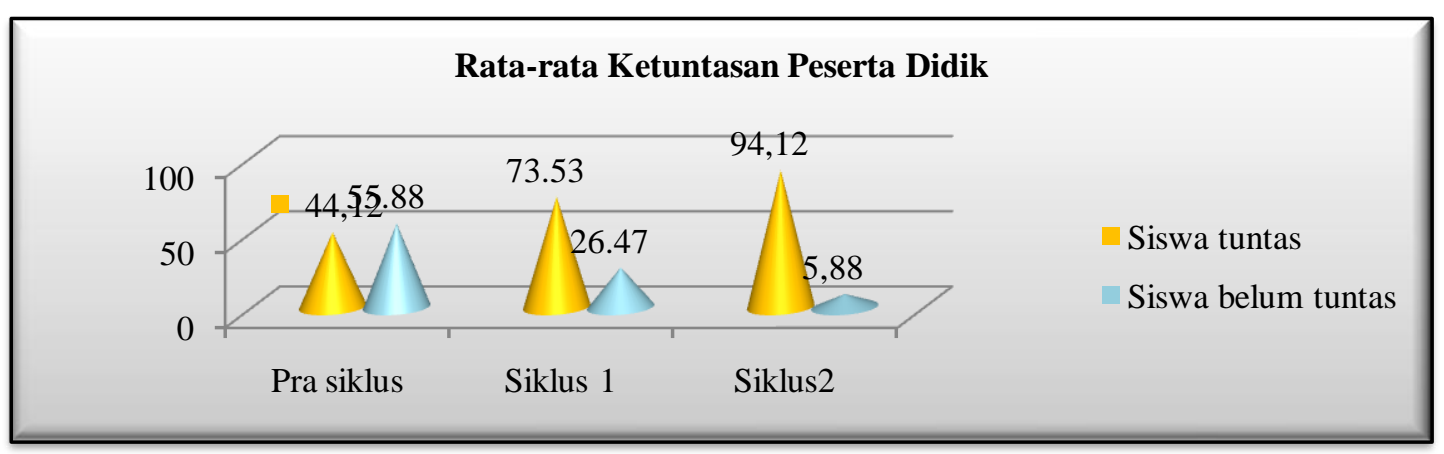

Grafik 2: Diagram ketuntasan hasil belajar peserta didik.

Dari tabel dan diagram diatas menunjukan telah terjadi peningkatan hasil belajar peserta didik dari data pra siklus sampai data siklus II, dimana peserta didik yang tuntas Pra siklus hanya 44,12\%, siklus I meningkat,73,53 dan siklus ke II peserta didik yang tuntas sudah mencapai 94,12\%. Dengan arti kata pada siklus II dari 34 peserta didik hanya 2 orang peserta didik yang belum tuntas.

Berdasarkan temuan penelitian pada siklus I yang dilaksanakan sebanyak 4 kali pertemuan, dari aktivitas yang diobservasi atau diamati yaitu bertanya, menjawab pertanyaan, kerjasama dalam kelompok , menyelesaikan tugas tepet waktu, keaktifan dalam kelompok dan semangat belajar, terlihat bahwa masing-masing aktivitas meningkat, dengan peningkatan persentase yang berbeda, Aktivitas yang paling tinggi terdapat pada aktifitas keaktifan dalam kelompok diskusi dan menyelesaikan tugas tepat waktu. Dan aktifitas yang paling rendah yaitu aktifitas bertanya dan presentase kedepan kelas. Dan kalau dilihat dari hasil belajar peserta didik dilihat dari ketuntasan klasikal sudah mencapai target yaitu $80 \%$ peserta didik yang tuntas dianggap penelitian ini behasil, tetapi dilihat secara individual tingkat ketidaktuntasan peserta didik masih tinngi, yaitu 9 orang peserta didik belum mencapai ketuntasan dengan perolehan nilai dibawah 75 .

Karena peningkatan aktivitas dan hasil belajar tersebut belum memuaskan dan juga berdasarkan hasil refleksi pada siklus I, maka dapat disimpulkan bahwa penerapan model pembelajaran Kooperatif Tipe Numbered Heads Together ini belum optimal. Untuk itu penelitian ini perlu dilanjutkan ke siklus II. Siklus II dilaksanakan besrdasarkan hasil dari refleksi siklus I, kelemahan-kelemahan yang ditemui pada siklus I diperbaiki pada siklus ke II.

Siklus ke II dilakukan sebanyak 4 kali pertemuan, dan dalam siklus ke dua ini dari setiap aktivitas yang diamati menunjukkan peningkatan yang cukup signifikan, Aktifitas yang paling tinggi terdapat pada aktifitas keaktifan dalam kelompok diskusi yaitu 91,19\% dan aktifitas yang paling rendah terdapat pada aktifitas bertanya yaitu $80,15 \%$. Tetapi secara keseluran aktivitas yang diamati pada siklus II ini sudah sesuai dengan indikator kinerja yaitu sudah mencapai tingkat ketuntasan klasikal 80\% maka penelitian sudah dianggap berhasil. Dan kalau dilihat dari hasil belajar peserta didik juga sudah mengalami peningkatan dimana pada siklus II peserta didik yang mencapai ketuntasan sudah mencapai 32 orang $(94,12)$ dan yang tidak tuntas, 2 orang $(5,88 \%)$. Bagi peserta didik yang belum tuntas perlu dilakukan remedial dan juga memberikan soal latihan agar ke depan hasil belajar dapat mencapai KKM.

Berdasarkan hasil analisis data siklus I dan siklus II maka penerapan model pembelajaran Numbered Heads Together dalam pembelajaran IPS dapat meningkatkan aktivitas dan hasil belajar peserta didik. Peserta didik lebih aktif belajar dan lebih bersemangat dalam belajar karena mereka belajar dalam kelompok yang dapat menjalin komonikasi dan kerja sama mereka dalam kelompok.Karena pada siklus I dan II ini aktivitas dan hasil belajar peserta didik telah mengalami peningkatan pada setiap indikator yang diamati dan target sudah sesuai dengan yang diharapkan, maka penelitian ini dicukupkan sampai siklus II.

Dengan demikian hasil analisis tindakan ini mendukung hipotesis tindakan yang diajukan yaitu jika diterapkan model pembelajaraan kooperatif Tipe Numbered Heads Together (NHT) dapat meningkatkan aktivitas dan hasil belajar peserta didik kelas IX.5 SMPN 5 Bukittinggi.

\section{KESIMPULAN}

Setelah dilakukan penelitian tindakan kelas selama dua siklus dan diperoleh persentase dan refleksi dari tiap - tiap siklus, maka dapat disimpulkan: 1) Pembelajaran koopertatif Tipe Numbered Heads Togeher dapat 
meningkatkan aktivitas belajar IPS peserta didik kelas IX.5SMP N 5 Bukitinggi. Aktivitas yang diamati diantaranya bertanya, menjawab pertanyaan, kerjasama dalam kelompok diskusi,menyelesaikan tugas tepat waktu, presentase kedepan kelas, keaktifan dalam kelompok, dan semangat belajar semua aktifitas ini dapat meningkatkan keaktifan peserta didik dalam belajar; 2) Pembelajaran kooperatif Tipe Numbered Head Togeher dapat meningkatkan hasil belajar peserta didik kelas IX.5 SMP N 5 Bukittinggi. Dari pra siklus, siklus I dan II hasil belajar terus mengalami peningkatan, pada siklus I peserta didik yang tuntas belajar 25 orang $(73,53 \%)$ dan siklus II peserta didik yang tuntas jadi 32 orang(94,12\%) dengan kategori Amat baik

\section{DAFTAR RUJUKAN}

Achsin, Amir. (1990). Pengelolaan Kelas dan Interaksi Belajar Mengajar. Ujung Pandang: IKIP Ujung Pandang.

Arikunto, Suharsimi. (1997). Prosedur Penelitian: Suatu Pendekatan Praktek. Yogyakarta: Rineka Cipta.

Arikunto, S. (2006). Prosedur Penelitian Suatu Pendekatan Praktis. Jakarta: Rineka Cipta

Muslim Ibrahim. (2000). Pembelajaran Kooperatif. Surabaya: University Press

Slavin, R.E (1983) Cooperative Learning. Maryland: John Hopkins Universit

Sardiman, A. M. (2006). Interaksi dan Motivasi Belajar Mengajar. Jakarta. PT. Raja Grafindo

Sudjana, Nana. ( 2005). Penilaian Hasil Proses Belajar Mengajar. Remaja Rosda Karya: Bandung

Silberman, Melvin L. (2009). Active Learning, 101 cara belajar Aktif. Bandung: Nusamedia

Siti, Fatimah. (2015). Modul Pembelajaran IPS. Padang: Prodi IPS Program Pascasarjana UNP.

Sudjana (2000). Strategi Pembelajaran. Bandung: Sinar Baru

Slameto. 1988. Evaluasi Pendidikan. Jakarta: Bumi Aksara

Sanjaya,Wina. (2007). Strategi Pembelajaran Berorientasi Standar Proses Pendidikan. Jakarta

Sardiman. (2009). Interaksi dan Motivasi Belajar Mengajar. Jakarta : PT. Raja Grafindo

Slavin, Robert. E. 2008. Cooperative Learning. Bandung: Nusa Media

Sumantri, Numan. (2001). Pembaharuan Pendidikan IPS. Bandung : Rosda Karya.

Lie Anita ( 2002). Cooperative Learning, Mempraktekkan Cooperative Learning di Raung- ruang Kelas: Jakarta, Gramedia

Trianto. (2007). Model-model Pembelajaran Inovatif Berorientasi Konstruktivistik. Jakarta: Prestasi Pustaka 